\title{
The Motivation of Women in Performing the Role of Mamak in Works of Local Minangkabau Literary Art
}

\author{
Firdaus $^{*} \quad$ Leni Efendi \\ Theater Department, Performing Arts Faculty \\ Institut Seni Indonesia Padangpanjang
}

\begin{abstract}
The goal of this research is to study the social phenomena related to the motivation of women in performing the role of mamak (uncle, mother's brother), and the effect of this on the matrilineal system which is actualized in local Minangkabau literature. The research uses a qualitative method and a content analysis with an approach of structuralism and literary sociology. The research data source is six titles of local Minangkabau literature chosen based on purposive sampling. The data analysis uses intrinsic and extrinsic methods. The research results show seven causative factors related to the decline in the role of mamak and two causative factors related to the motivation of women in performing the role of mamak. The values contained in the motivation of women performing the role of mamak include courage to defend justice, an unyielding spirit, and responsibility to family. This influences the system of values in the matrilineal system of Minangkabau, by weakening the role of mamak, strengthening the role of the nuclear family, and causing a shift in the kinship structure within the family.
\end{abstract}

Keywords: Minangkabau women, role of mamak, local literature, motivation.

DOI: $10.7176 / \mathrm{ADS} / 83-03$

Publication date:July $31^{\text {st }} 2020$

\section{Introduction}

Minangkabau is a part of Indonesia with a rich local or regional culture which is often used as a basis for creating works of literature. Writers from Minangkabau in particular make their own culture a prominent feature of literary works that are published throughout Indonesia and abroad. Local Minangkabau literature refers to works of literature that portray the life of the Minangkabau community with all its different aspects of behaviour and culture. Numerous works of local Minangkabau literature have been written in the form of prose or stories, including stories such as Cindua Mato, Sabai Nan Aluih, Sitti Nurbaya, Orang-Orang Blanti, Si Padang, Anak Bako, Anggun Nan Tongga, Giriang-giriang Perak, and so on.

The large number of literary works with a background of Minangkabau culture have given rise to the term local Minangkabau literature. The term local here can be equated to the word regional or ethnic; it refers to everything that is connected with local culture, regional culture, or ethnic culture. In this understanding, a work of local literature must have a unique style or idiom that is not found in other areas outside its own locality. According to Kusmarwanti (2008), characteristics of cultural richness emerge in the plot (in particular in the development of the conflict), the characters (in their names and personalities), and the background (place, time, and social setting).

One of the strongest features of the Minangkabau people is the kinship system, which follows a matrilineal system. A matrilineal culture is one which follows the line of descent (nasab) from the mother's side. The strength of matrilineal culture in this area is evident from the special attention given to women. On a certain level, women in Minangkabau hold a special status in that they are in charge of all matters related to inheritance. This applies in particular for married women, who are often referred to as bundo kanduang. Every woman (bundo kanduang) owns ancestral land or communal property (Zaleka, 2007). As the person who manages the household, the bundo kanduang plays a strong role in determining the good and bad of family members. As members of the community who are known as sumarak dalam nagari (ornaments in the village), bundo kanduang play a prominent role; without women, a community would be lacking a significant element.

The special importance of Minangkabau women is symbolized as limpapeh rumah nan gadang (the main pillar of the house). This means they are like the central pillar of a building on which the weight of all the other pillars rests. If this one pillar breaks, others will follow. When a Minangkabau woman marries, as a wife she will take on additional duties that must be carried out with wisdom, mutual respect, and skilful capability.

Meanwhile, according to Minangkabau custom, the position of men at a certain point in time will become mamak. In the matrilineal family structure in Minangkabau, mamak is the name given to the (younger or older) brother from the mother's side of the family. In the traditional structure of Minangkabau culture, the mamak is the man who is in charge of a clan or group. Every person in the community belongs to a clan, and every clan is headed by a mamak, or better known as datuak (headsman). Ideally, a mamak is highly revered in Minangkabau. He plays a significant role in the life of his nephews and nieces, or the children of his sisters. There is a traditional Minangkabau proverb which illustrates the role of the mamak: "Kaluak paku kacang balimbiang, tampuruang lenggang-lenggokan. Anak dipangku kamanakan dibimbiang, urang kampuang dipatenggangkan" (Curves of the fern and nut of the star fruit, the shell swinging and swaying. Child is on the lap, nephew/niece is guided, people 
of the village are taken into consideration). This means that the mamak has a multiple function, to take care of his own children, his nephews and nieces, and the people of the village. In addition, it is the mamak's role to look after and develop his legacy or inheritance.

In Minangkabau tradition, men and women have an equal status. Men have the right to control everything in their own clan, including controlling the use and division of inheritance. As the 'owners', women can use the inheritance for their own needs. Men in Minangkabau have two functions: first, as a father who is head of the household and responsible for his wife and children; and second, as a mamak who plays an important role in guiding his nephews and nieces in customary and religious matters, and in their day to day behaviour.

The ideal role of the mamak and women - specifically bundo kanduang - in the social life of the Minangkabau community is regulated by customary law. However, it is an interesting phenomenon when this ideal, in particular the role of the mamak, is disputed and negated by writers through their works of literature. The role of the mamak is no longer as it should be but instead is taken over or replaced by women. This means that women are becoming mamak. From a number of works of local Minangkabau literature studied in this research, it is found that the role of the mamak is being taken over by women. For example, the character Sabai Nan Aluih in the story (kaba) Sabai Nan Aluih, which tells about the courage of Sabai Nan Aluih in defending the honour of her family. In kaba Siti Baheram, the bravery of the character Siti Baheram is shown when she leaves the house to search for her husband, even though the situation is dangerous. Similarly, the character Sitti Nurbaya in the novel Sitti Nurbaya has the courage to challenge Datuk Maringgih who has destroyed her family's life. In fact, these problems faced by Siti Baheram, Sabai Nan Aluih, and Sitti Nurbaya should really be resolved by the mamak. The phenomenon in which the role of the mamak is taken over by women in several examples of local Minangkabau literature will be discussed in this research.

\section{Method}

This research uses a qualitative descriptive method with a content analysis which places local Minangkabau literature as the primary data. Explicitly, the principle for implementation of a content analysis is interpretation. The qualitative method and content analysis are used to interpret the results of local Minangkabau literature which reflect the reality of the social and cultural life of its community. In this case, interpreting the structure of local Minangkabau literature is primarily concerned with the causative factors related to the decline in the role of mamak, the motivation of women performing the role of mamak, and the values contained in the literature that are based on the social and cultural system of Minangkabau.

The research data source is six works of local Minangkabau literature ( $2 \mathrm{kaba} /$ stories, 2 novels, and 2 short stories), which were chosen through purposive sampling based on a number of considerations. These considerations were: (1) literary works that include a mamak figure, and (2) literary works that feature female characters. Based on these considerations, the 6 data sources chosen were: (1) the story Cindua Mato by Syamsudin St. Rajo Endah, (2) the story Sabai Nan Aluih by M. Rasyid Manggis, (3) the novel Sitti Nurbaya by Marah Rusli, (4) the novel Orang-Orang Blanti by Wisran Hadi, (5) the short story Si Padang by Haris Efendi Tahar, and (6) the short story Anak Bako by A.R. Rizal.

Data in the form of identified abstractions or events was analyzed inductively. In an inductive data analysis, according to Bogdan and Miklen (in Emzir, 2010: 3-4), the theory for the data analysis is determined after the data has been collected, in relation to the goals of the research, so the approaches chosen here are an objective approach or structuralism, and a mimesis approach or literary sociology. For this purpose, the research data is analyzed in two stages. The first stage is an intrinsic analysis, using the approach of structuralism with the theory of (pure) structuralism developed by A. Teeuw, and the second stage is an extrinsic analysis, using the literary sociological approach developed by Umar Junus. The structuralism approach is needed to obtain information about the literary elements while the literary sociological approach is needed to discover the meaning contained in these literary elements in relation to the social and cultural system of the community.

Based on these approaches, the data analysis was carried out using the following steps. First, an intrinsic study about the literary structure of the chosen samples to obtain information and gain a clear picture of the plot, background, characters and characterization, and the theme of the story. Second, an extrinsic study to understand the meaning of the story with regard to the role of the mamak and the role of women, and the interconnection between the two. In order to gain a real picture about the interconnection between these roles, a thematic analysis was performed. In other words, the analysis focussed on the role of the mamak and the role of the women based on the theme or main idea of the story. In this case, both roles were analyzed according to the main problems faced by the characters in the story. In carrying out the analysis, it was important to look at the problems faced by the characters from the point of view of the connection between the two roles rather than the point of view of the characters, because the problems would become clearer when one role was connected to the other. Third, a discussion and interpretation of the results of the findings about the factors that motivate women to perform the role of mamak, and about the values that are oriented towards the social and cultural system of Minangkabau. The interpretation or assigning of meaning was carried out hermeneutically, or using the hermeneutic circle. This 
method was applied to understand the meaning from both sides, beginning with an overall interpretation of a temporary nature and subsequently interpreting the data section by section. This kind of sectional interpretation is helpful for perfecting the temporary interpretation in order to achieve an interpretation of meaning which encompasses the entire text of the literary work. The process of interpretation in this study began by looking at the prominent elements, in particular the conflict in the stories. The interpretation of the story themes observed the prominent conflict experienced by the main characters, while in the interpretation of the roles of the women and the mamak, the conflict observed was related to the connection between the roles involving female characters and mamak characters in a particular problem. The intrinsic meaning was then revealed by connecting the hidden meaning in the story with the social and cultural system of Minangkabau or the traditional philosophy of the community. This was done by choosing a dialectic method that moves from explanation towards understanding.

\section{Results and Discussion}

The discussion and analysis starts with the six literary works studied. Therefore, a short description is needed of each work, as a basic reference for the analysis.

\subsection{Description of the Literary Works Studied}

This short description is intended to give a brief outline of the six literary works studied. The first work selected for this research is the fourth edition of the story/kaba Cindua Mato by Syamsudin Sutan Rajo Endah, published by Pustaka Indonesia, Bukittinggi, in 1987. Based on the plot, background, characters, and characterization it can be said that the theme of kaba Cindua Mato is oppression that cannot defeat good. The tyrant king Rajo Imbang Jayo is unable to defeat the good king Raja Pararuyung. All the trickery, provocation, and vilification of Rajo Imbang Jayo directed towards Raja Pagaruyung ultimately does more harm to himself and destroys his kingdom. Rajo Imbang Jayo makes false accusations about Raja Pagaruyung seizing Puti Bungsu (the fiancee of Dang Tuangku) and Rajo Mudo betrays a promise made to his own mother (Bundo Kanduang).

The second story chosen for this research is kaba Sabai Nan Aluih by M. Rasyid Manggis Dt. Rajo Penghulu, edited by Arfizal Indramaharaja and published by Kristal Multimedia, Bukittinggi, in 2004. Based on the plot, background, characters, and characterization of kaba Sabai Nan Aluih, it can be said that the theme of the story is oppression that cannot defeat justice and truth. The tyranny of the king Rajo Nan Panjang towards the king Rajo Babandiang is an act of injustice. This act is denounced by the character Sabai Nan Aluih (the daughter of Rajo Babandiang) and ends with the death of Rajo Nan Panjang.

The third work of literature chosen as a sample for the research is the $17^{\text {th }}$ edition of the novel Sitti Nurbaya by Marah Rusli, published by Balai Pustaka, in 1986. Based on the plot, background, characters, and characterization in the novel Sitti Nurbaya it can be seen that the theme of the novel is oppression that cannot defeat justice. The tyranny of Datuk Maringgih towards Baginda Sulaiman causes more harm to himself. In addition, it is evident that a certain group in the community, specifically the younger generation, has the desire to break down traditions that are no longer deemed suitable for the developments in the present day, but in the end they fail to do so. This is represented by the characters Sitti Nurbaya and Samsul Bahri.

The fourth work taken as a sample for this research is the novel Orang-Orang Blanti by Wisran Hadi, published by Yayasan Citra Budaya Indonesia, Padang, in 2000. Based on the intrinsic analysis of the characters and characterization, along with the plot and background of the story, it can be seen that the theme presented in the novel Orang-Orang Blanti is the conflict of interests regarding the use of communal land and inheritance in the Minangkabau community. This is represented by Datuk Tuo (a native of Blanti) a clan leader who betrays his clan in order to retain the title of datuk, and as a result, the communal land belonging to his clan changes hands. Gampo Alam (a newcomer) forces his own wishes to own the communal land in the village of Blanti. Using various means and ways, he seizes the inherited land of the Blanti people, enabling him to gain great wealth and power in the village of Blanti.

The fifth work studied is the short story Si Padang by Harris Effendi Thahar, found in the first edition of a collection of short stories entitled Si Padang, published by Kompas Media Nusantara, Jakarta, in February 2003. Based on the plot, background, characters, and characterization, it can be seen that the theme presented in the short story Si Padang is the effect of modernization on the life system of Minangkabau settlers, which has weakened the role of the mamak as the leader of a clan and a member of the community. This can be seen from the attitude and behaviour of Haji Kiram, the mamak and head (penghulu or datuk) of his clan, who only cares about his own interests and neglects his duties to his nephews and nieces.

The sixth work chosen as a sample for this study is the first edition of the short story Anak Bako by A.R. Rizal which is contained in a collection of short stories with the title Jodoh untuk Juhana, published by Singgalang, Padang, in 2015. based on the plot, background, characters and characterization, it can be seen that the theme of Anak Bako is the different thought patterns, principles, or views of two generations - the older generation and the younger generation. The older generation, represented by Etek Piah and other mamak, measures a person's success in life from the point of view of the success they achieve in their job, regardless of their education. This is different 
from the younger generation, represented by Kamila and Agus, who tend to measure a person's success from their degree of independence in life. In order to achieve such independence, a good education and good skills are needed.

\subsection{Intrinsic Analysis}

From the intrinsic analysis of the 6 chosen samples of local Minangkabau literature, the themes of the stories can be grouped into 2 categories: (a) story themes prior to independence and (b) story themes after independence. The themes of the stories in local Minangkabau literature from the first category, written prior to independence, generally present moral problems in the Minangkabau community. This is evident in the actions of Rajo Imbang Joyo, who defames Raja Pagaruyung in order to seize Puti Bungsu (Dang Tuangku's fiancee) and the betrayal of Rajo Mudo, who breaks his promise to his mother (Bundo Kanduang) in kaba Cindua Mato.

Another example is the behaviour of Rajo Nan Panjang, who kills Rajo Babandiang (the father of Sabai Nan Aluih) because his request to take Sabai Nan Aluih for his wife is rejected, in kaba Sabai Nan Aluih. Similarly, Datuk Maringgih, who is no longer young and already has a wife, wishes to take Sitti Nurbaya as his second wife as a way of paying off the debts of his father (Baginda Sulaiman) in the novel Sitti Nurbaya. All of these examples of evil behaviour spark conflict and lead to a battle which results in death. Thus, the theme of local Minangkabau literature prior to independence is concerned with moral issues, specifically the oppression or evil deeds that cannot defeat truth or justice.

The post independence themes differ in that they present problems related to the struggle for freedom and pride or self worth. More specifically, they present problems that go against the traditional and cultural norms, and the social values of the community. This is evident from the conflict of interests experienced by the characters in the novel Orang-orang Blanti. The character Datuk Tuo betrays his clan because he is afraid of the people in power and because of the oath he has taken, and as a result the communal land of his clan changes hands. In fact, the use of this inheritance has already been regulated and it should not be allowed to be sold or to change hands. Similarly, in the short story Si Padang, the character Haji Karim is only concerned with his own interests and neglects his duties as a mamak in his clan. According to Minangkabau custom, a mamak has multiple functions, namely as a mamak in his clan and as a father in his own family. As a mamak, Haji Karim is obliged to guide and take care of his nephews and nieces and to guard the inheritance of his clan. Hence, the theme of local Minangkabau literature after independence presents social issues that go against the traditional and cultural norms of the community.

The Minangkabau people belong to an ethnic community that adheres to a matrilineal kinship system, or a system that follows the line of descent from the mother's side. The ideal pattern of this matrilineal system is a strong and mutually binding relationship between the mamak and his nephews and nieces. However, in reality, the relationship between a mamak and his nephews and nieces is not always harmonious, and at times the mamak fails to perform his role in an ideal way. Through these works of local Minangkabau literature it is possible to examine the disharmony in relationships between a mamak and his nephews and nieces.

From the results of the intrinsic analysis of local Minangkabau literature, it can be seen that the story themes can be grouped into two categories: (a) story themes from the era prior to Indonesian independence (before 1945), which in general present moral issues, specifically tyranny or oppression that cannot defeat truth or justice; and (b) story themes from the era of Indonesian post independence, which tend more to promote issues of struggle for freedom and pride. The plots of pre-independence stories generally use a chronological or conventional plot or storyline, while those of post independence stories use non-conventional or modern plots. With regard to the background of local Minangkabau literature, the settings used are generally neutral and typical. In literature published prior to independence, writers tend more towards typical backgrounds, or settings that have or promote regional characteristics, whether in terms of place, time, or social setting. After independence, neutral backgrounds are more prominent. The characters and characterization in local Minangkabau literature prior to independence is inclined to portray simple characters with flat or static personalities. Nurgiyantoro (2009: 189) writes that in static characterization, there are what is known as black characters (with evil or antagonistic connotations) and white characters (with good or protagonistic connotations). After independence, literature contains characters that are more rounded or complex, with personalities that continue to develop and evolve. From the perspective of the techniques used for portraying the characters, local Minangkabau literature, as with literature in general, uses various analytic or expository techniques and dramatic techniques. Analytic techniques are used to portray character through description, illustration, or direct explanation, while dramatic techniques portray character in an indirect manner. Dramatic techniques include conversational techniques, behavioural techniques, techniques of thought and feeling, techniques involving the reaction of the character, the reaction of other characters, and techniques describing the setting or background.

\subsection{Extrinsic Analysis}

From the results of the extrinsic analysis it was found that a number of the mamak's roles have begun to disappear or undergo a shift, and are no longer being carried out as they should. The decline in the role of the mamak in 
Minangkabau is seen in the conflict faced by some of the characters in the novel Orang-Orang Blanti. Based on the background or setting of the events in this novel, it is clear that the events take place during the time of the New Order government. Law number 5 Year 1979 about the lowest government system, which was first implemented in West Sumatra in 1983 based on Regional Regulation Number 13 Year 1983, replacing the government system of the nagari (the lowest government system, at the level of the village, based on the concept of Minangkabau government), became the new village government system. The effect of this new regulation was a decline or weakening in the role of the mamak in the life of a village or nagari. The customary institution of the mamak was replaced with another institution known as Lembaga Ketahanan Masyarakat Desa (LKMD), established by the New Order government. Today, despite the fact that the New Order Regime has already been replaced with the Reformation Regime, which passed Law Number 22 Year 1999 about Regional Autonomy, allowing the West Sumatra government to respond by establishing the "Return to Nagari Movement", first implemented in 2001, it will nevertheless take a long time and special efforts to restore the role of the mamak. Nowadays, people have more confidence in reporting a problem directly to the local government rather than to the mamak.

The causative factors related to the weakening role of the mamak include social status in the family. Ideally, a family should have a son first before a daughter so that he can more quickly prepare his responsibilities for becoming a mamak and take charge over his younger sister(s). This is the opposite from the family situation in all the chosen samples of short stories, in which the daughter is older than the son. This factor presents an obstacle for a mamak because he may feel reluctant or unwilling to take charge of his older sister, in accordance with the traditional philosophy which states, "Nan tuo dimuliakan, nan ketek dikasiahi, samo gadang bawo bakawan, ibu bapo labiah sakali (the older one is respected, the younger one is loved and cared for, those of the same age become friends, mother and father are held in higher esteem)." In accordance with the fatwa to honour those who are older, a mamak would feel reluctant to take charge over his older sister.

The way children are educated by their parents also influences the formation of a child's attitude and character. This is evident in the story Sabai Nan Aluih in which there is a family without a mamak because the character Sadun Saribai does not have a brother. In the development of the story, a son, Mangkutak Alam, is born. After reaching adulthood, he should take on the role of mamak but he fails to take on this role and function, and does not even care when his family is tyrannized by another person. Mangkutak Alam allows his family to be dishonoured by Rajo Nan Panjang. The character of Mangkutak Alam was shaped by the way his parents (specifically his father) spoiled him while he was growing up, and as a result he was unaware that he should perform the duties and responsibilities of a mamak. His character was formed by the way his parents (father) treated him, which conforms to the traditional proverb: "Dek ketek taanjo-anjo, lah gadang tabawo-bawo, lah tuo tarubah tido, sampai mati jadi parangai (if a child is spoiled, this will be carried over into adulthood, it won't even change in old age, it will be his temperament until his death)."

The decline in the role of the mamak is also related to the current of modernization and globalization that have led to the penetration and infiltration of cultures from outside. Although the Minangkabau community is an ethnic group with its own cultural territory, developments in transportation and mass communication technology are becoming ever more sophisticated, making changes in tradition unavoidable. These shifts and changes not only cause structural changes in the community but also substantial changes. One of the negative impacts is a change in people's behaviour, which is becoming more prestige oriented, materialistic, and individualistic. This is found in the short story Si Padang. The character Haji Kiram (the mamak) who is a successful businessman outside the Minangkabau homeland, has been carried away by the current of modernization, showing an example of the traditional fatwa: "Alah limau dek mindalu, ilang pusako dek pancarian (a lime/orange is defeated by a parasite, heritage is lost because of livelihood)." According to Abidin (2008), the basic foundation of traditional Minangkabau culture is "adat basandi syarak, syarak basandi Kitabullah," which means there is a strong cultural foundation that hinges closely on religion (syarak - Islamic law). Therefore, the Minangkabau people should combine these two essential values - custom and syarak - inside themselves. In this way, tradition should be viewed as an effort by individuals and by the community to respond to their life challenges. Tradition is not only wealth from the past but also a part of the present.

Besides the factors mentioned above, in Islam the family system also influences the social structure of the Minangkabau community. Sahrul (2009: 423) states that during the Paderi war, wahabi teachings, or the radical teachings of Islam, influenced Minangkabau culture. All the people in Minangkabau were required to understand and practice Minangkabau cultural values while adhering to the teachings of Islam. Islamic teachings state that a man, as head of his household, must provide for his family. The total and complete application of tradition and religion influences the social structure within the family. It is the father who determines everything for his children. In the novel Sitti Nurbaya, the power of the father's role is evident in the actions of the character Sutan Mahmud who drives out his son (samsul Bahri) without any discussion with the mamak. This is also the case in the story Sabai Nan Aluih, in the actions of Rajo Babandiang, who fulfils all the wishes of his son (Mangkutak Alam), without any regard for the feelings of his wife and daughter. This attitude, of a father who is concerned only about 
his own immediate family, and cares little for his extended family or his clan, goes against the traditional fatwa: "Kaluak paku kacang balimbiang, tampuruang lenggang lenggokan, bawo lalu ka Saruaso. Anak dipangku kamanakan dibimbiang, urang kampuang dipatenggangkan, jago nagari jan binaso (Curves of the fern and nut of the star fruit, the shell swinging and swaying, carried to Saruaso. Child is on the lap, nephew/niece is guided, people of the village are taken into consideration, guard the country so that it does not perish)." This means that in Minangkabau, a man who holds the role of mamak has multiple functions.

Until now, there are no legal sanctions for a mamak who violates customs or traditions. The actions of Rajo Nan Panjang (in the story Sabai Nan Aluih), seizing the hand of Sabai Nan Aluih from her father (Rajo Babandiang), the tyranny of Datuk Maringgih towards Sitti Nurbaya (in the novel Sitti Nurbaya), and the selling of communal land by Datuk Tuo (in the novel Orang-Orang Blanti) are all examples of violations of Minangkabau customs. These violations by a mamak are yet to receive any clear legal sanctions, when in fact there is a fatwa in Minangkabau tradition which states: "Nagari bapaga undang, kampuang bapaga buek, tiok lasuang baayam gadang, salah tampuah buliah diambek (The nagari is surrounded by laws, the kampung is surrounded by rules, every clan has a leader/custodian, if they do wrong, their entrance can be blocked)." This means, every nagari (village) in Minangkabau is already governed by its own regulations.

The incompatibility and indecision of the mamak is another reason for a decline in their role. The paradoxical attitude of Datuk Tuo in the novel Orang-Orang Blanti when facing his clan is contradictory to his attitude when he faces authority figures such as Gampo Alam. The attitude of this mamak is described in the proverb: "Bajua bamurah-murah, batanyo jawab batimbang, rang gadang tak samo arah, di sinan rakyat makonyo bimbang (selling too cheap, asking and answering too many considerations, if leaders are not compatible, it makes their people uncertain)." This means that if a mamak does not have an opinion and if there is no unity between the mamak and his clan, it will lead to the destruction of their clan.

From the explanation above, it can be seen that in some instances mamak no longer perform their role as they ideally should in Minangkabau tradition, and this has led to the motivation of women to take over this role. From an etymological perspective, the word motivation comes from the Latin word 'motivus' or 'motum' which means to move or drive. Based on the origins of this word, Loren Bagus (in Lianto, 2008) defines motivation or motive as a conscious urge, stemming from an action, to formulate certain human needs. Motivation plays an important role in evaluating human actions because motives contain the subjective meaning of certain actions for certain people.

According to the limitations of the word motivation described above, the motivation of women in local Minangkabau literature is based on a sense of shame for their family pride. Sabai Nan Aluih performs the role of mamak after being triggered by a sense of shame about the actions of Rajo Nan Panjang who has killed her father. The character Bundo Kanduang takes on the role of mamak after feeling shame about Rajo Imbang Jayo defaming her in order to seize Dang Tuangku (her daughter) as his fiancee. Based on the life principle of togetherness, shame in the Minangkabau community is shared and faced together. Therefore, the motivation of women performing the role of mamak contains the values of courage to defend truth, a spirit of never giving up, and responsibility to family. In Minangkabau there is a traditional fatwa which states: "Sajangka tak namuah lalu, satapak tak kunjuang suruik, indak dipandang jauah hampia, nan bana tagakkan juo (a span will not pass, a step will not recede, not viewed as far or near, truth is also upheld)." This traditional fatwa shows that although Minangkabau women are gentle, they hold firm to their life principles. The success of women in performing the role of mamak is supported by a sense of togetherness which is one of the life principles of the Minangkabau community.

The emergence of women's motivation to perform the role of mamak has an effect on the value system in the matrilineal system of Minangkabau. This includes weakening the mamak's role, both in the saparuik family (the main family unit of a grandmother) and the extended family or clan. This taking over the role of the mamak by women also strengthens the role of the nuclear family, because the role of the mother and father become increasingly important in the family. In addition, the motivation of women in performing the role of mamak gives rise to a shift in the kinship structure within the family. This is evident in the increasing lack of concern of the mamak for his nieces and nephews, along with the decline in curiosity of the nephews and nieces about their duties and obligations as members of the community.

\section{Conclusion}

Works of local Minangkabau literature are a reflection of the life structure of the Minangkabau community. One of the important issues revealed in local Minangkabau literature is the decline in the role of the mamak which has impacted the Minangkabau matrilineal system. This has triggered the motivation of women to take over the role of the mamak. This motivation contains values which imply that Minangkabau women have a gentle character but at the same time adhere firmly to their life principles. The impact of the motivation of women performing the role of mamak on the Minangkabau matrilineal system is to weaken the role of the mamak, strengthen the role of the nuclear family, and cause a shift in the kinship structure within the family. Even though existentially there has been a shift in the system of values in the matrilineal system in Minangkabau, in its substance the Minangkabau 
matrilineal system can still be preserved because it is an essential part of the identity of Minangkabau. This shows that Minangkabau custom is flexible, or open to reform, while at the same time holding onto its principles. Something that comes from outside can be used as long as it does not harm the customary values that are the spirit of Minangkabau.

\section{References}

Abidin, Mas'oed. (2008), Posisi dan Peran Bapak sebagai Kepala Keluarga dalam Masyarakat Hukum Adat Minangkabau. http://blogMinangkabau.wordpress.com.

Abidin, Mas'ud. (2004), Implementasi Adat Basandi Syarak, Syarak Basandi Kitabullah, Padang: Pusat Pengkajian Islam dan Minangkabau (PPIM) Sumatra Barat.

Burhan, Nurgiyantoro. (2009), Teori Pengkajian Fiksi. Yogyakarta: Gadjah Mada University Press.

Endah, Syamsudin Sutan Rajo. (1987), Cindua Mato fourth edition. Bukittinggi: Pustaka Indonesia.

Emzir. (2008), Metodologi Penelitian Pendidikan Kuantitatif \& Kualitatif. Jakarta: Rajagrafindo Persada.

Hadi, Wisran. (2000), Orang-Orang Blanti. Padang: Yayasan Citra Budaya Indonesia.

Kusmarwanti. (2008). 'Warna' Lokal Minangkabau Dalam Karya Sastra Indonesia. Yogyakarta: UNY

Penghulu, M. Rasyid Manggis Dt. Rajo. (2004). Sabai Nan Aluih, disunting oleh Arfizal Indramaharaja. Bukittinggi: Kristal Multimedia.

Rizal, A.R. (2015), Anak Bako. In Kumpulan Cerita Pendek: Jodoh untuk Juhana first edition. Padang: Singgalang.

Rusli, Marah. (1986), Sitti Nurbaya 17the edition. Jakarta: Balai Pustaka.

Sahrul N. (2009), "Budaya Islam Minangkabau dalam Drama Perang Paderi Karya Wisran Hadi.” Journal Panggung vol. 19 no. 4, October - December, ISBI Bandung.

Thahar, Harris Effendi. (2003), Si Padang. In Kumpulan Cerita Pendek Si Padang first edition. Jakarta: Kompas Media Nusantara.

Teeuw, A. (1988), Sastra dan Ilmu Sastra: Pengantar Teori Sastra. Jakarta: Pustaka Jaya.

Umar Junus. (1986), Sosiologi Sastra: Persoalan Teori dan Metode. Kuala Lumpur: Dewan Bahasa dan Pustaka, Kementerian Pelajaran Malaysia.

Zaleka Hg. (2007), "Perempuan Minangkabau Antara Realitas dan Harapan" in Nanang Subakti et al. eds. Membangun Masa Depan Minangkabau Dari Perspektif Hak Azasi Manusia. Padang: Komisi Nasional Hak Azasi Manusia Fakultas Hukum Universitas Andalas. 